\title{
An Analysis of Errors in Craniometry
}

\author{
Makiko KOUCHI and Kiyotaka KOIZUMI \\ Department of Anthropology, Faculty of Science, \\ The University of Tokyo
}

\begin{abstract}
Twenty-six measurement items taken three times on 35 crania by 10 observers independently were analysed for the influence of careless mistakes and measurement errors. The median number of careless mistakes per trial was 7.5. Nested analysis of variance showed that 8 measurement items had greater than $10 \%$ total error variance (Table 1 ). The influence of careless mistakes and inter-observer error on population comparison was examined by cluster analyses of several distance coefficients. The results indicated that the influence of mistakes could be minimized by eliminating the outlying measurements outside the range of $\bar{x} \pm 3 \mathrm{~S}$. D., and that the measurement items with greater total error variance should be excluded to minimize the influence of inter-observer measurement errors.
\end{abstract}

Keywords Craniometry, Measurement error, Analysis of variance

\section{Introduction}

Many studies have been published on measurement error in somatometry (DAVENPORT et al. 1934; SUZUKI, 1935; GAVAN, 1950 ; HiRATA, 1950 ; NAKAO et al., 1972; SPIELMAN et al., 1972; JAMISON and Zegura, 1974 ; Kemper and PIETERs, 1974 ; IKEDA and TERADA, 1977; KOUCHI and HANIHARA, 1981), but there are few studies on measurement error in craniometry. This is probably because the consistency of cranial measurements has been taken for granted, for they are not inflenced by factors such as posture, respiration, compressibility of the soft tissues etc. Recently SAKURA and Mizoguchi (1983) analysed the intra- and inter-observer measurement errors in popular cranial measurement items by nested analysis of variance. Their analysis was based on only five crania and their results might be biased because of sampling problems. PAGE (1976) studied the effect of interobserver error in craniometry on a principal component analysis, but two observers measured different sets of crania in his data.

Careless mistakes can not be completely avoided and their influence on population comparison should not be ignored. However, this aspect of error has never been analysed.

The purposes of the present study are: 1) to study the frequency and nature of

Article No. 8511 Received May 14, 1985. 
careless mistakes ; 2) to study the magnitude of intra- and inter-observer measurement errors in some popular craniometric measurement items; and 3) to examine what steps should be taken to minimize the effects of careless mistakes and measurement errors in multivariate population comparison.

\section{Materials and Methods}

The materials used for the present study were 35 relatively well preserved crania of the Edo period from the Unkoin series excavated at Unkoin temple, Fukagawa, Koto-ku, Tokyo. All the crania were sexed as male by one of the authors (K.K.). In the present study ten observers independently measured each of the 35 crania three times in order to detect careless mistakes. The 26 measurement items taken are shown in Table 1. All were measured according to MARTIN und SALLER (1957), except for upper facial height, nasal height and the four radial measurements according to Howells (1973). Three of the ten observers had had a lot of experience, and four had taken a course of training in craniometry in the Department of Anthropology, Faculty of Science, The University of Tokyo. The remaining three did not have any experience, but were instructed on the detailed definition of the landmarks and measuring methods before they started the research.

Another set of 30 crania from the Unkoin series were measured by K.K. (Unkoin-2), and 26 crania of the Edo period from the Higashiueno series (Higashiueno), excavated at Higashiueno, Taito-ku, Tokyo, were measured by M.K., and were used for comparison. All the crania were relatively well preserved and sexed as male by K.K. These two series of crania belong to the Department of Anthropology and
Prehistory, University Museum, The University of Tokyo. Also, the basic statistics of 65 male crania of the Edo period from Joshinji temple, Fukagawa, Koto-ku, Tokyo, reported by Commission of Anthropological Investigation of Modern Japanese Crania (1983), were used for comparison. The Joshinji series was measured by one of the present observers.

Nested analysis of variance (SOKAL and ROHLF, 1981) was used to test the significance of the differences between the intraand inter-observer variances and between the inter-observer and among-skull variances. Whether the measurement errors have a serious influence on the data or not should be judged by another criterion than the Ftest. For this purpose, the total variance was partitioned into the three components, intra- and inter-observer error variances and among-skull variance, and the proportion of each component was calculated. When the total error variance is less than $10 \%$ of total variance, the measurement items are tentatively considered to be reliable.

To minimize the effects of careless mistakes, a screening step was adopted and measurements outside the range of $\bar{x} \pm 3$ S. D. were eliminated in each subsample. To examine the influence of careless mistakes and measurement errors on multivariate analysis, mean square distances, PENROSE's size and shape distances, and MAHALANOBIS' generalized distaces among the populations were calculated and analysed by cluster analysis based on the following five sets of measurement items: 1) 26 measurement items without any mistakes corrected ; 2) 26 measurement items after the above-mentioned screening without any mistakes corrected; 3) 26 measurement items with mistakes corrected ; 4) 18 measurement items with 
less than $10 \%$ total error variance and mistakes corrected ; 5) 18 measurement items after the screening without mistakes corrected. Thirty-four populations were used for this analysis: 30 subsamples (three trials by ten observers), average of the series based on the medians of 30 observations for each measurement (Unkoin-1), and the three groups used for Comparison (Unkoin-2, Higashiueno and Joshinji).

Standard deviations and the variancecovariance matrix based on 65 crania of the Unkoin series measured by K.K. were used to calculate PENRose's distances and MAHALANOBIS' generalized distances respectively. The weighted group average method of cluster analysis was used.

The exclusion of measurement items with greater than $10 \%$ total error variance might cause a serious loss of information. Therefore, the data of 65 crania of the Unkoin series measured by K. K. were analysed by factor analysis, and the importance of the measurement items with greater error variances in terms of the uniqueness of information was examined. The data were analysed by program BMDP4M with varimax rotation. All the calculations for the factor analysis were processed by the HITAC $\mathrm{M} 200 \mathrm{H}$ system of the Computer Centre of The University of Tokyo.

When the measurement items with greater total error variance were excluded to minimize the influence of measurement errors, the relationship among the populations might have been altered because of the loss of information. Also, the screening step may not be efficient enough to minimize the inflence of careless mistakes. The consistency of the relationship among the populations can be ascertained if the measure of accordance between the two sets of distance coefficients is high. In the present study, PENROSE's shape distance was used as a distance coefficient, and the distances between the four populations, Unkoin-1 (average based on the medians of subsamples), Unkoin-2, Higashiueno and Joshinji, were calculated based on the following three sets of measurement items: 1) 26 measurement items with mistakes corrected ; 2) 18 measurement items with less than 10\% total error variance with mistakes corrected; 3 ) 18 measurement items after the screening step without any mistakes corrected. As a measure of accordance, PEARSON's correlation coefficient was calculated between the distance coefficients based on the above three sets of measurement items.

\section{Results}

I. Careless mistakes

Since each observer measured the same cranium three times, careless mistakes could be detected. Among about 900 measurements in one trial (26 measurement items for 35 crania) the number of mistakes ranged from 0 to 51 with the median 7.5. About 70\% of these mistakes were mistakes in reading the caliper by $5 \mathrm{~mm}$ or by $10 \mathrm{~mm}$ and mistakes from filling in the wrong places of the protocol. The experienced observers tended to make a smaller number of mistakes, but the inexperienced did not necessarily make many mistakes.

By the screening step of eliminating the measurements outside the range of $\bar{x} \pm 3 \mathrm{~S}$. D., the mistakes whose differences with the correct values were greater than $20 \mathrm{~mm}$ were eliminated, but the mistakes in reading by $5 \mathrm{~mm}$ or $10 \mathrm{~mm}$ were not.

Since these careless mistakes were caused by different factors from those responsible for the measurement errors, they were 
replaced by new measurements taken by the observers concerned.

\section{Nested Analysis of Variance}

Nested analysis of variance was based on the data with no missing observations among the 30 trials ( 3 trials by 10 observers). The results are shown in Table 1 . All the Fvalues were significant at the 0.005 level: in all the measurement items inter-observer error variance was significantly greater than intra-observer error variance, and amongskull variance was significantly greater than inter-observer error variance. Inter-observer error variance was greater than intra-observer error variance, particularly in biauricular breadth, sagittal parietal arc, sagittal occipital arc, sagittal parietal chord and

Table 1. Results of nested anlysis of variance.

\begin{tabular}{|c|c|c|c|c|c|c|c|}
\hline \multirow{2}{*}{\multicolumn{2}{|c|}{$\begin{array}{l}\text { MARTIN's } \\
\text { no. }\end{array}$}} & \multirow{3}{*}{$\begin{array}{c}\text { F1 } \\
3.06\end{array}$} & \multirow{3}{*}{$\begin{array}{c}\text { F2 } \\
774.75\end{array}$} & \multicolumn{4}{|c|}{ component of variance } \\
\hline & & & & \multirow{2}{*}{$\begin{array}{c}\text { Intra-obs. } \\
1.24 \%\end{array}$} & \multirow{2}{*}{$\frac{\text { Inter-obs. }}{0.85 \%}$} & \multirow{2}{*}{$\begin{array}{l}\text { Total } \\
\text { error }\end{array}$} & \multirow{2}{*}{$\begin{array}{c}\begin{array}{c}\text { Among } \\
\text { skulls }\end{array} \\
97.91 \%\end{array}$} \\
\hline 1 & Maximum cranial length & & & & & & \\
\hline 2 & Cranial base length & 2.11 & 622.83 & 2.22 & 0.82 & 3.04 & 96.96 \\
\hline 8 & Maximum cranial breadth & 3.30 & 613.61 & 1.45 & 1. 11 & 2.55 & 97.45 \\
\hline 9 & Minimum frontal breadth & 2.52 & 1006.69 & 1.16 & 0.59 & 1.75 & 98.25 \\
\hline 11 & Biauricular breadth & 21.18 & 16.64 & 5.33 & 35.84 & 41.16 & 58.84 \\
\hline 17 & Basion-bregma height & 2.45 & 1185.57 & 1.02 & 0.49 & 1.51 & 98.49 \\
\hline 26 & Sagittal frontal arc & 1.71 & 1304.09 & 1.32 & 0.31 & 1.64 & 98.36 \\
\hline 27 & Sagittal parietal arc & 23.60 & 44.62 & 2.33 & 17.58 & 19.92 & 80.08 \\
\hline 28 & Sagittal occipital arc & 21.93 & 51.10 & 2.24 & 15.64 & 17.89 & 82.11 \\
\hline 29 & Sagittal frontal chord & 1.43 & 1701.74 & 1.22 & 0.17 & 1.39 & 98.61 \\
\hline 30 & Sagittal parietal chord & 15.00 & 50.07 & 3.31 & 15.45 & 18.76 & 81.24 \\
\hline 31 & Sagittal occipital chord & 17.38 & 64.39 & 2.32 & 12.64 & 14.96 & 85.04 \\
\hline 40 & Facial length & 3.78 & 339.12 & 2.25 & 2.08 & 4.33 & 95.67 \\
\hline 45 & Bizygomatic breadth & 2.20 & 2284.20 & 0.59 & 0.24 & 0.83 & 99.17 \\
\hline 46 & Middle facial breadth & 5.58 & 136.02 & 3.62 & 5.52 & 9.14 & 90.86 \\
\hline$*$ & Upper facial height & 2.70 & 209.68 & 4.92 & 2.78 & 7.70 & 92.30 \\
\hline 51 & Orbital breadth I & 2.23 & 51.98 & 19.27 & 7.87 & 17.14 & 72.86 \\
\hline $51 \mathrm{a}$ & Orbital breadth II & 3.32 & 45.17 & 15.00 & 11.61 & 26.62 & 73.38 \\
\hline 52 & Orbital height & 2.59 & 132.08 & 7.79 & 4.12 & 11.92 & 88.08 \\
\hline 54 & Nasal breadth & 2.15 & 214.30 & 6.00 & 2.30 & 8.30 & 91.70 \\
\hline$*$ & Nasal height & 3.36 & 163.38 & 5.00 & 3.94 & 8.94 & 91.06 \\
\hline 61 & Upper alveolar breadth & 1.73 & 1381.77 & 1.23 & 0.30 & 1.54 & 98.46 \\
\hline & Vertex radius & 2.90 & 499.82 & 2.00 & 1.27 & 3.27 & 96.73 \\
\hline$*$ & Nasion radius & 2.37 & 470.03 & 2.60 & 1. 18 & 3.79 & 96.21 \\
\hline$*$ & Subspinal radius & 3.51 & 348.65 & 2.35 & 1.97 & 4.32 & 95.68 \\
\hline$*$ & Prosthion radius & 3.51 & 444.66 & 1.86 & 1.56 & 3.42 & 96.58 \\
\hline
\end{tabular}

*: Howells (1973)

F1: Inter-observer variance/Intra-observer variance

F2: Among skull variance/Inter-observer variance

All the $F$ values were significant at the 0.005 level 
sagittal occipital chord. When the original measurements were inspcted, the measurements taken by the same observers were very close to each other, but those taken by different observers tended to differ considerably in these measurement items. In biauricular breadth, most of the crania showed considerable between-observer discrepancy, so that the determination of the landmark, auriculare, seemed to differ according to the observer. In the other four measurement items, considerable interobserver discrepancies were observed only in those crania in which the landmark, lambda, must be estimated because of suture closure or presence of a sutural bone.

Among-skull variances were rather small for the inter-observer error variance in the above-mentioned five items, orbital breadth I and orbital breadth II.

The total variance was partitioned into three components: intra- and inter-observer error variances and among-skull variance. The percentages of these three components, as well as that of total error variance, are also shown in Table 1. If the proportion of total error variance is small enough, then the item can be judged as reliable. The criterion for this judgement is arbitrary. When total error variance less than $5 \%$ is taken as the criterion, all the facial measurements such as upper facial height, nasal breadth, nasal height, middle facial breadth, orbital breadth I, orbital breadth II and orbital height should be excluded. Though the smaller the total error variance the better, it is not desirable to lose too much information by setting an overly strict criterion. When the criterion of total error variance smaller than $10 \%$ is adopted, the measurement items which should be excluded are the following eight: biauricular breadth, orbital breadth I, orbital breadth II, sagittal parietal arc, sagittal occipital chord, sagittal occipital arc, sagittal parietal chord and orbital height. Apart from orbital height, the other seven of these" measurement items show particularly great inter-observer error variances, and thus the measurement error in them may have considerable influence on population comparison.

An observer often records a measurement value with "?" when he is not confident of the value because of slight damage to the cranium or suture closure etc. In the above nested analysis of variance, the measurements with "?" were also used, and this might have inflated the total error variance. Therefore, nested analysis of variance was applied to the data with no missing observations among the 30 after the measurements with "?" were eliminated. The results are shown in Table 2.

There is little difference for the results of measurement items with less than 10\% total error variance in the first analysis. In the six items with greater than 10\% total error variance in the first analysis (sagittal parietal arc, sagittal occipital arc, sagittal parietal chord, sagittal occipital chord, orbital breadth I and orbital breadth II), the percentage of total error variance did decrease, but was still greater than $10 \%$. Greater intra-observer error variances of orbital breadth I and orbital breadth II indicate that their reproducibilities are not good even when the same observer takes the measurement twice. For the other four items, different observers seem to use different lambda with confidence.

\section{Cluster Analysis}

The influence of careiess mistakes and measurement errors on the distance coefifici- 
Table 2. Results of nested anlysis of variance. Unreliable measurement values are excluded from the data.

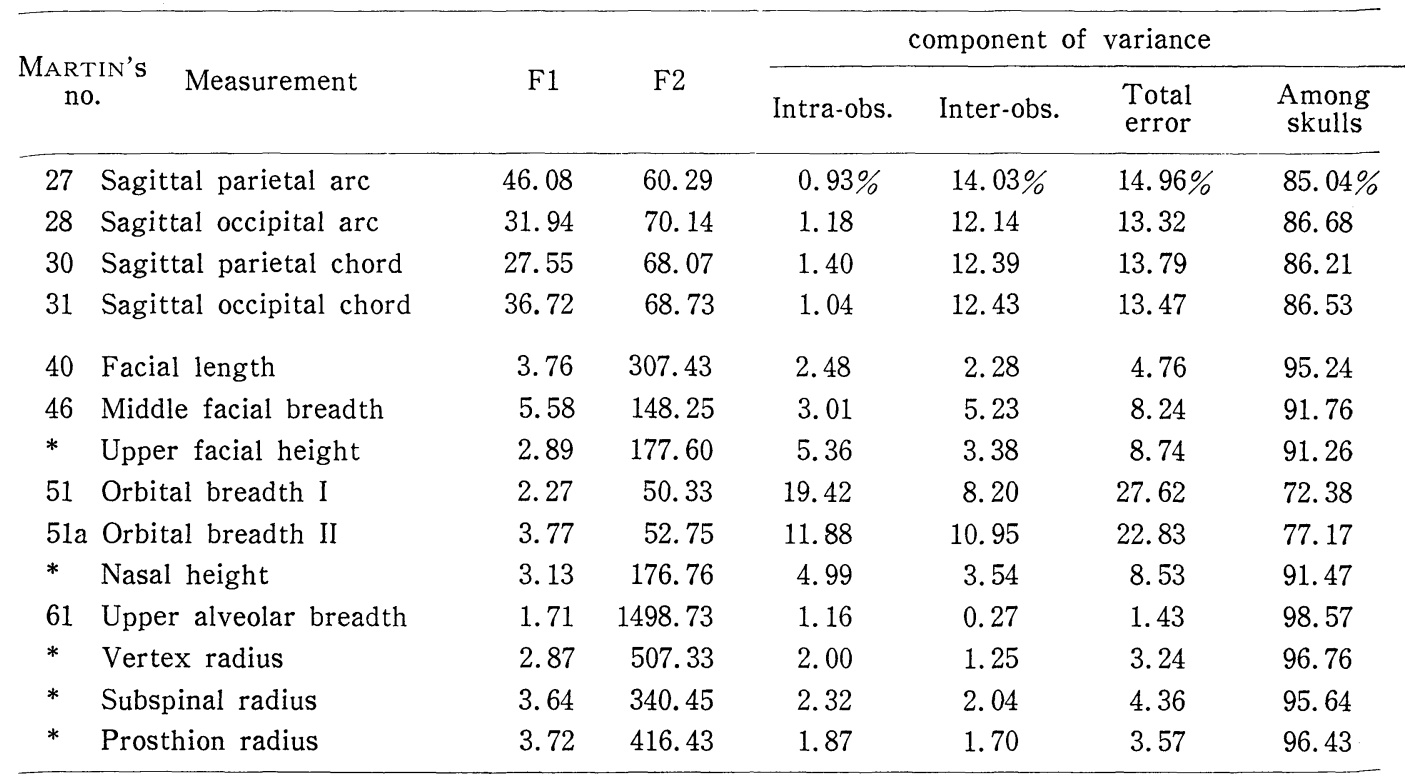

*: Howells (1973)

F1: Inter-observer variance/Intra-observer variance

F2: Among skull variance/Inter-observer variance

All the $\mathrm{F}$ values were significant at the 0.005 level

ents was analysed by cluster analysis. The results of cluster analysis based on PENROSE's size distances were not informative because they did not show any clear pattern. The results based on mean square distances and MAHALANOBIS' generalized distances were generally consistent with the results based on Penrose's shape distances. Therefore, only the results based on shape distances will be shown here.

1. Analysis based on 26 measurement items without any mistakes corrected:

The dendrogram (Fig. 1) shows the 30 subsamples by 10 observers divided into three main clusters. The three different populations (Unkoin-2, Higashiueno and Joshinji) were not separated from the 31 populations based on the same series of crania. Also, there is one subsample diverged widely from the other subsamples. 2. Analysis based on 26 measurement items after screening without any mistakes corrected :

Fig. 2 shows that the overall distance decreased drastically and that the one subsample which diverged widely from all the other subsamples in Analysis 1 joined the two subsamples by the same observer. Generally, the three subsamples by the same observer tend to make a single small cluster. The 31 populations based on the same crania were not separated from the other cranial populations.

3. Analysis based on 26 measurement items with mistakes corrected:

Fig. 3 shows that the results of this 
analysis is very similar to that of Analysis 2 (Fig. 2). This indicates the efficacy of the screening step in minimizing the influence of careless mistakes. However, the 30 subsamples are still divided into three main clusters. It is clear that this was not caused by careless mistakes but by inter-observer measurement errors. In fact, observers $F$, $\mathrm{H}$ and $\mathrm{J}$ tend to measure biauricular breadth systematically smaller than other observers. Observer $G$ tends to measure orbital breadth I systematically larger than and orbital breadth II systematically smaller than the other observers.

To minimize the influence of inter-observer measurement errors, 8 measurement items with greater than $10 \%$ total error variance (biauricular breadth, orbital breadth I, orbital breadth II, sagittal parietal arc, sagittal parietal chord, sagittal occipital arc, sagittal occipital chord and orbital height) were excluded from further analysis.

4. Analysis based on 18 measurement items with mistakes corrected:

The values of shape distance decreased after the 8 measurement items were excluded. The dendrogram (Fig. 4) shows that the 30 subsamples and Unkoin-1 based on the same series of crania made one cluster and they were clearly separated from the other populations based on the different cranial series. There is no tendency for the subsamples by experienced observers to form one cluster, and this suggests that experience does not play an important role in determining landmarks.

The distance from the origin to nod 1 in Fig. 4 can be considered to be due to measurement error, and the distance from the origin to nod 3 to be due to sampling error. PENROSE's shape distances based on the 18 measurement items among the 30 subsamples ranged from 0.001 to 0.059 , and those among the 30 subsample and Unkoin2 ranged from 0.042 to 0.093 . The corresponding MAHALANOBIs' generalized distances ranged from 0.038 to 7.963 , and from 3.988 to 12.672 , respectively. Fig. 4 also suggests that the sampling error can not be ignored.

5. Analysis based on 18 measurement items after screening without any mistakes corrected :

The shape distance is generally a little greater than in Analysis 4, where there were no mistakes. Shape distances between the 30 subsamples ranged from 0.001 to 0.067 , and those between Unkoin- 2 and the 30 subsamples ranged from 0.037 to 0.088 . The corresponding MAHALANOBIs' generalized distances ranged from 0.093 to 7.774 and from 4.144 to 15.423 , respectively. Fig. 5 shows that the relationship among the populations is also a little different from that in Fig. 4: the 30 subsamples were clearly separated from Unkoin-2 and Higashiueno but not from Joshinji.

\section{Factor Analysis}

Eight factors with eigenvalues greater than 1 before varimax rotation explained about $83 \%$ of the total variance. Table 3 shows the results after varimax rotation. Among 8 measurement items with greater than $10 \%$ total error variance, orbital height did not have a high correlation with any of the eight factors. Therefore, the loss of information caused by exclusion of orbital height may not be serious even if it carries unique information.

Sagittal occipital arc and sagittal occipital chord are highly correlated with the 2nd factor, sagittal parietal chord and sagittal parietal arc with the 4th factor, orbital 


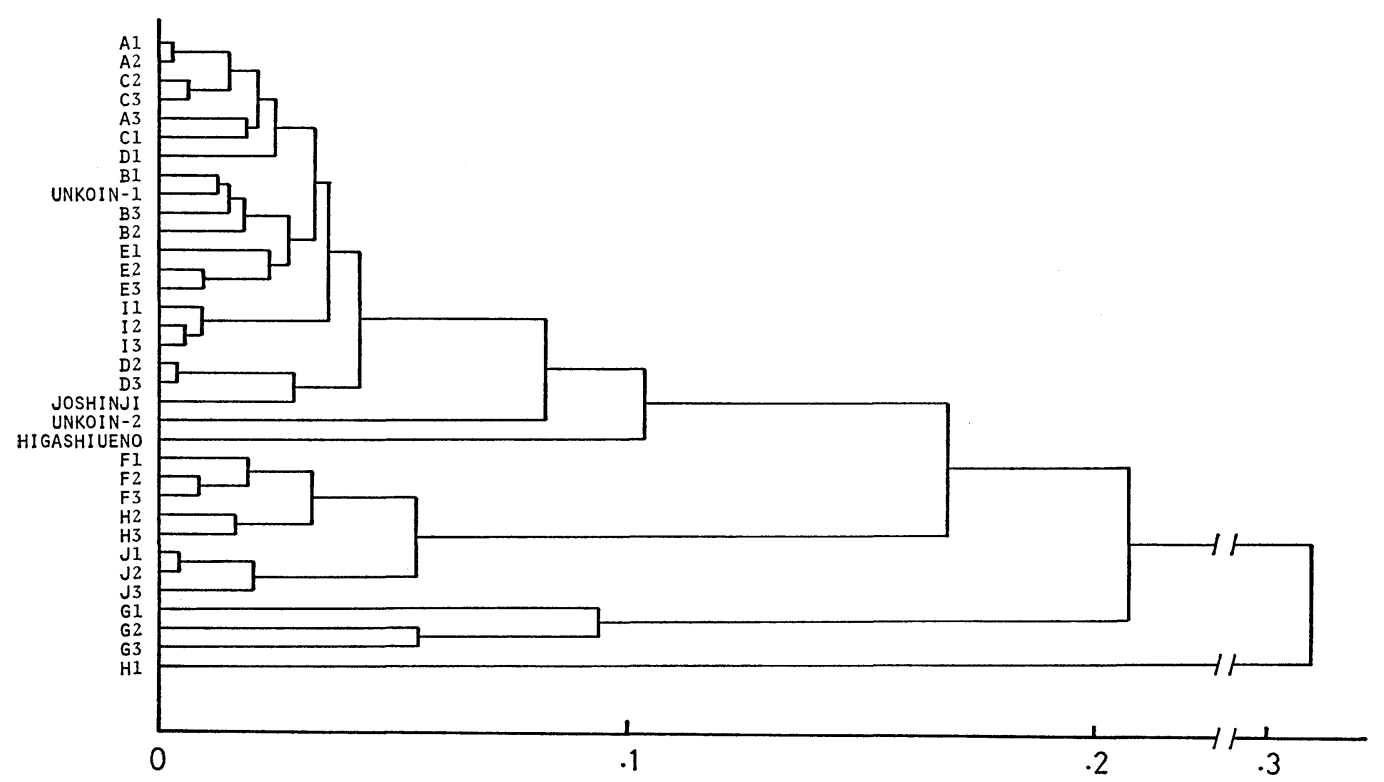

Fig. 1. Cluster analysis of the male Japanese cranial series from the Edo period using PENROSE's shape distance based on 26 measurement items without any mistakes corrected (Analysis 1).

Note: A to J denote the ten observers, and 1 to 3 the three observation tests on the same 35 crania from the Unkoin series. Unkoin-1: average based on the median of the 30 observations by observer A to J.; Unkoin-2: The 30 crania also from the Unkoin series.; Higashiueno: The 26 crania from the Higashiueno series.; Joshinji: The 65 crania from the Joshinji series (Commission of Anthropological Investigation of Modern Japanese Crania, 1983).

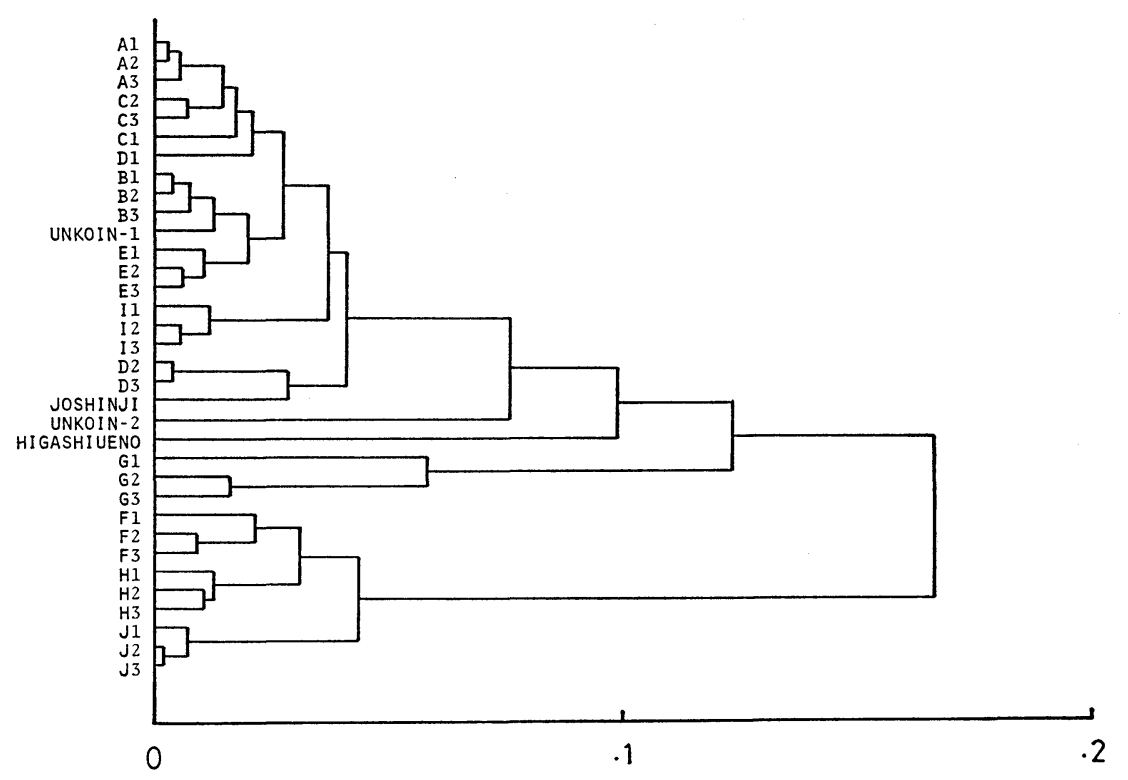

Fig. 2. Cluster analysis of the male Japanese cranial series from the Edo period using PENROSE's shape distance based on 26 measurement items after screening and without any mistakes corrected (Analysis 2). See note of Fig. 1. 


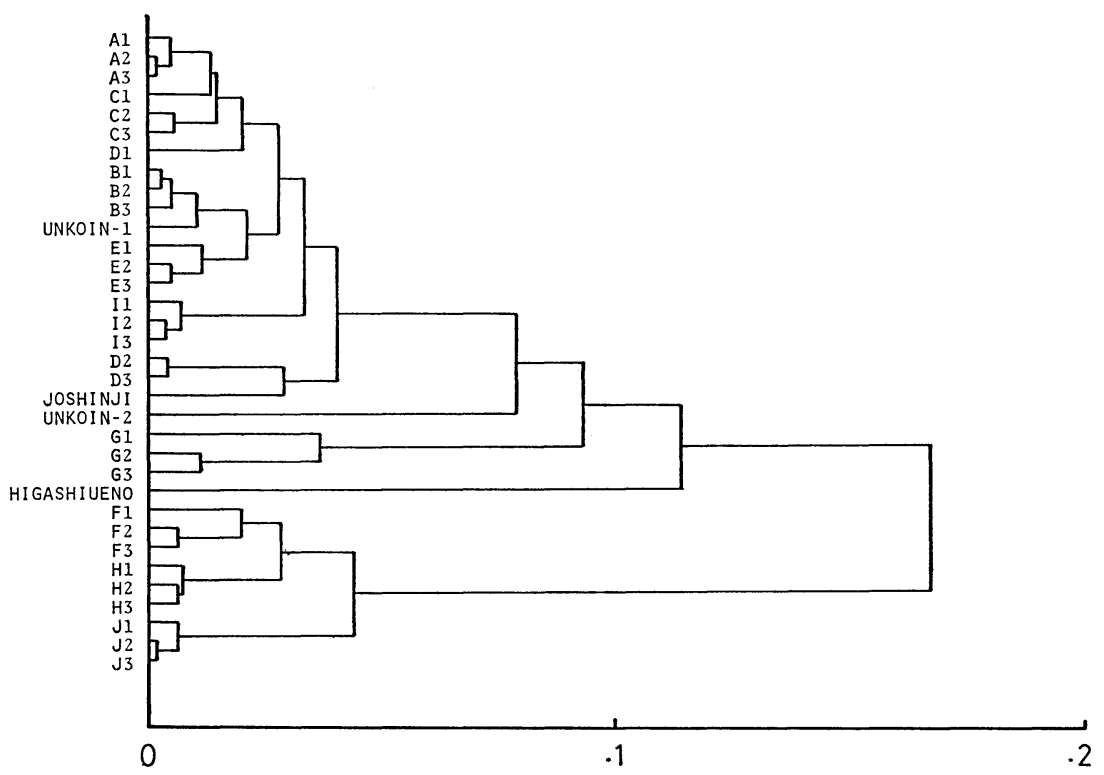

Fig. 3. Cluster analysis of the male Japanese cranial series from the Edo period using PENROSE's shape distance based on 26 measurement items with mistakes corrected (Analysis 3). See note of Fig. 1.

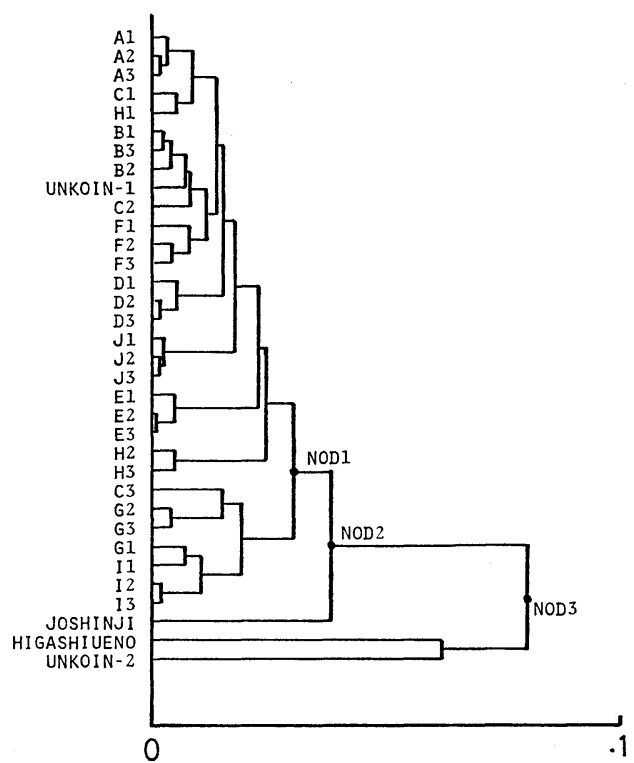

Fig. 4. Cluster analysis of the male Japanese cranial series from the Edo period using PenRose's shape distance based on 18 measurement items with mistakes corrected (Analysis 4). See note of Fig. 1.

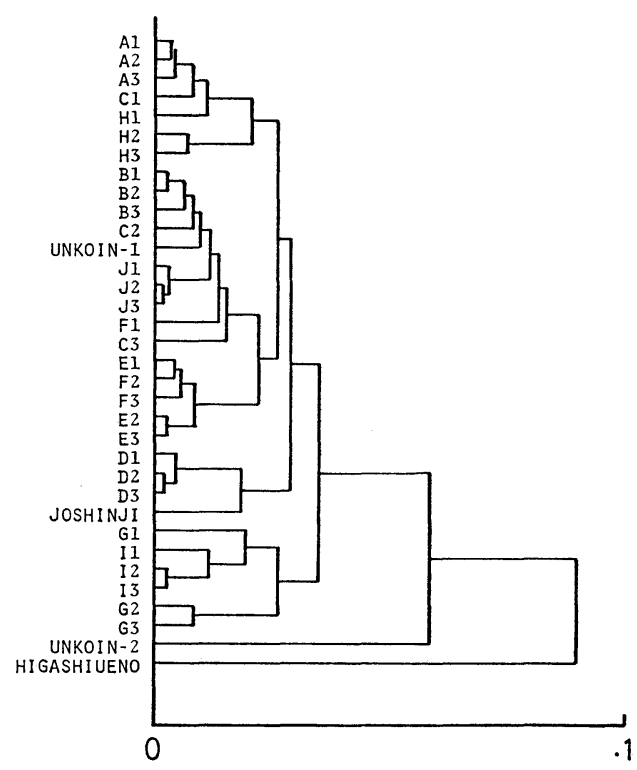

Fig. 5. Cluster analysis of the male Japanese cranial series from the Edo period using PenRose's shape distance based on 18 measurement items after screening without any mistakes corrected (Analysis 5). See note of Fig. 1. 
Table 3. Results of factor analysis. Factor loadings after varimax rotation. Factor loadings greater than 0.316 are shown.

\begin{tabular}{|c|c|c|c|c|c|c|c|c|}
\hline Measurement & $\mathrm{FC} 1$ & $\mathrm{FC} 2$ & $\mathrm{FC} 3$ & $\mathrm{FC} 4$ & FC5 & FC6 & $\mathrm{FC} 7$ & $\mathrm{FC} 8$ \\
\hline Subspinal radius & .864 & & & & & & & \\
\hline Prosthion radius & .767 & & .319 & & & & & \\
\hline Cranial base length & .738 & .321 & & & & & & .349 \\
\hline Nasion radius & .728 & & & & & & & \\
\hline Facial length & .711 & & & .398 & & & & \\
\hline Sag. occipital arc & & .915 & & & & & & \\
\hline Sag. occipital chord & & .834 & & & & & & \\
\hline Cranial length & .500 & .651 & & & & & & \\
\hline Sag. frontal chord & & & .841 & & & & & \\
\hline Sag. frontal arc & & & .817 & & & & & \\
\hline Cranial breadth & & & .638 & & & & & \\
\hline Nasal breadth & .362 & & .554 & & & & .347 & \\
\hline Sag. parietal chord & & & & .957 & & & & \\
\hline Sag. parietal arc & & & & .913 & & & & \\
\hline Orbital breadth I & & & & & .906 & & & \\
\hline Orbital breadth II & & & & & .849 & & & \\
\hline Min. frontal breadth & & & & .412 & .605 & & & \\
\hline Nasal height & & & & & & .769 & & \\
\hline Upper facial height & & & .335 & & & .728 & & \\
\hline Upper alveolar breadth & & & & & & .728 & & \\
\hline Middle facial breadth & & & & & & & .789 & \\
\hline Biauricular breadth & .390 & & & & & & .711 & \\
\hline Bizygomatic breadth & .501 & & & & & & .660 & \\
\hline Basion-bregma height & & & & & & & & .941 \\
\hline Vertex radius & & & & & & & & .782 \\
\hline Orbital height & & -.485 & & & & .428 & & \\
\hline Variance explained by the factor & 3.96 & 2.85 & 2.75 & 2.66 & 2.48 & 2.29 & 2.28 & 2.18 \\
\hline
\end{tabular}

breadth I and orbital breadth II with the 5th factor, and biauricular breadth with the 7th factor. As the 7th factor is highly correlated not only with biauricular breadth but also with bizygomatic breadth and middle facial breadth, the loss of information caused by excluding biauricular breadth may not be serious either. The 2 nd and the 5 th factors have rather high correlations with maximum cranial length and minimum frontal breadth, respectively. However, the information on the parietal bone would be almost completely lost if sagittal parietal chord and sagittal parietal arc were excluded. As for orbital breadth I and orbital breadth II, a considerable part of their variances reflects not morphological variation but the difficulty of determining the measuring points judging from their great intra-observer error variances. 
Table 4. Correlation coefficients between the PENROsE's shape distances among the four populations (Unkoin-1, Unkoin-2, Higashiueno and Joshinji) based on the 3 sets of measurements.

\begin{tabular}{|c|c|c|c|c|}
\hline & Shape distance & 1 & 2 & 3 \\
\hline 1 & 26 measurement items with mistakes corrected & 1. & & \\
\hline 2 & 18 measurement items with mistakes corrected & $.868^{*}$ & 1. & 1. \\
\hline 3 & 18 measurement items after screening without mistakes corrected & $.868^{*}$ & 1. $* *$ & 1. \\
\hline
\end{tabular}

* significant at the 0.05 level

** significant at the 0.01 level

It seems that the loss of information caused by the exclusion of the measurement items with greater than 10\% total error variance is not negligible.

V. Correlations between the Shape Distances

PEARSON's correlation coefficient between the shape distances is shown in Table 4. When there are no mistakes, the correlation coefficient between shape distaces based on 26 and 18 measurement items was 0.868 and significant at the 0.05 level. This suggests that the relationships among the populations did not change greatly in spite of the loss of information caused by the exclusion of the 8 measurement items. A correlation coefficient as high as 1.0 between the shape distances based on 18 measurement items with the mistakes corrected and those without any mistakes corrected but having undergone screening indicates the efficacy of this step, that is, of screening, in minimizing the influence of careless mistakes.

\section{Discussion}

SAKURA and Mizoguchi (1983) analysed measurement errors in craniometry using nested analysis of variance, and their results were compared with the present results. In the present results, all the $\mathrm{F}$-values were highly significant partly because of very large degrees of freedom. Therefore, the percentages of total error variance instead of the significance of the F-values were compared (Table 5).

Nineteen measurement items were analysed in common in SAKURA and MizoguchI and the present study. A rather large discrepancy in the percentage of total error variance was observed in the following four measurement items: minimum frontal breadth, biauricular breadth, sagittal parietal arc and sagittal occipital arc. In biauricular breadth, the discrepancy was caused by the fact that the landmark, auriculare, was determined in two different ways by the present observers.

In the other three measurement items, however, the crania, not the observers, may have caused the discrepancy. The measuring point lambda had to be estimated in 12 out of 35 crania used in the present study. If lambda could have been determined without difficulty in these crania, the percentage of total error variance in the present study may have been much smaller and closer to the values reported by SAKURA and MizoGUCHI. Minimum frontal breadth was one of the very reliable measurement items in the present study, but it showed large interobserver error in SAKURA and MIZOGUCHI. If the right and left temporal lines ran in such a way that the landmarks, frontotemporale, could not be easily determined even in a single cranium out of the five 
Table 5. Comparison of proportion of total error variance.

\begin{tabular}{rlcc}
\hline MARTin's no. Measurement & SAKURA \& MizOGUCHI (1983) & Present study \\
\hline 1 & Maximum cranial length & $0.87 \%$ & $2.09 \%$ \\
5 & Cranial base length & 1.38 & 3.04 \\
8 & Maximum cranial breadth & 2.70 & 2.55 \\
9 & Minimum frontalobreadth & 15.44 & 1.75 \\
11 & Biauricular breadth & 5.07 & 41.17 \\
17 & Basion-bregma height* & 2.17 & 1.51 \\
26 & Sagittal frontal arc & 1.10 & 1.64 \\
29 & Sagittal frontal chord & 1.12 & 1.39 \\
30 & Sagittal parietal chord & 5.23 & 18.77 \\
31 & Sagittal occipital chord & 1.55 & 14.96 \\
40 & Facial length & 3.16 & 4.33 \\
45 & Bizygomatic breadth & 0.85 & 0.83 \\
46 & Middle facial breadth & 5.36 & 9.14 \\
$* *$ & Upper facial height & 4.83 & 7.70 \\
51 & Orbital breadth & 57.49 & 27.14 \\
52 & Orbital height & 10.09 & 11.92 \\
54 & Nasal breadth & 2.64 & 8.30 \\
$* *$ & Nasal height & 2.71 & 8.94 \\
61 & Upper alveolar breadth & 1.85 & 1.54 \\
\hline
\end{tabular}

* Measurements by SaKura and Mizoguchi were taken according to Howells (1973).

** Howells (1973).

they used, the error variance might have been inflated. It may be safer not to estimate the landmark when it is difficult to determine it.

The present results coincide with those of SAKURA and MizoGuchI in the inconsistency of orbital measurements.

The influence of mesurement errors on the population comparison have been discussed (SPIElman et al., 1972; PAGE, 1976), but the influence of careless mistakes has failed to arouse the interest of anthropologists. It is very difficult to avoid careless mistakes completely, however careful one might be (only one trial among the 30 was free from careless mistakes in the present study), and the comparison of the results of cluster analyses 1 and 3 (Figs. 1 and 3) shows that this could have a serious effect on the inter- population comparison. However, this effect can be minimized by a screening step to eliminate measurements outside the range of $\bar{x} \pm 3$ S. D. when original data are available. Mistakes in reading the caliper by $5 \mathrm{~mm}$ or by $10 \mathrm{~mm}$ can not be eliminated by this screening method, but their effects are not systematic but random, and their influence on population comparison may not be serious.

In the analysis of population relationship, one of two strategies must be chosen to take into account the effects of interobserver measurement errors. They are: 1. to use as many variables as possible and to interpret the results after careful consideration of measurement errors ; and 2. to select reliable variables only, though this leads to the loss of some information. 
There is no practical and reasonable way to interpret the results giving careful consideration to measurement errors, because it is impossible to know the nature of interobserver measurement errors, especially when data from published papers are used. The only practical way to minimize the effects of inter-observer measurement errors is not to use unreliable measurement items.

However, whether a measurement item should be used or not depends on the populations to be compared. When comparison is made between the main racial stocks and morphological differences are rather great, the influence of measurement errors may not be very serious. However, when the morphological differences between the populations are small, for example, when geographic variations in the modern Japanese are to be studied, the influence of interobserver measurement errors can be very serious. The three populations used for comparison in the present study are from the same area and period as the Unkoin series, and one of them is a different sample from the Unkoin series, so that the morphological differences between the skeletal populations used in this study are considered to be very small. Since the 30 subsamples made a single cluster in the cluster analysis 4 based on 18 measurement items (Fig. 4), these 18 measurement items are considered very reliable.

The results of the factor analysis indicated that the exclusion of the measurement items with greater than $10 \%$ total error variance naturally caused a loss of information. In fact, the relation between the populations altered to some extent when a different set of measurement items was used. However, the results of cluster analyses strongly suggest that it would be safe to choose the second strategy, especially when the morphological difference among the populations are small. If the measurement items which have been shown to have greater interobserver errors are to be used for population comparison, the best method is for all the measurements to be taken by the same observer. When this is impossible, the landmarks should not be estimated when they can not be determined without difficulty.

\section{Acknowledgements}

The authors wish to express their gratitude to Dr. Banri Endo, Department of Anthropology, Faculty of Science, The University of Tokyo, for his kind permission to examine the crania. They also wish to express their thanks to Mr. WANG Ling Hong, Institute of Vertebrate Palaeontology and Palaeanthropology, Academia Sinica, People's Republic of China, Mr. Eiichi Miyashiro, Department of Archaeology, Faculty of Letters, Meiji University, Mrs. Mariko HasegawA, Mr. Katsuyoshi Misumi, Miss Akiko UCHIDA, Mr. Hitoshi Wakisaka, Mr. Kiyoshi Sakata and Mr. Katsumi Kondo, Department of Anthropology, Faculty of Science, The University of Tokyo, for their participation in the present research.

\section{References}

Commission of Anthropological Investigation of Modern Japanese Crania, ed., 1983: Data for geographical variations in modern Japanese crania. II. Tokyo.

[現代日本人頭骨研究班編，1983：現代日本人頭骨 の地理的変異に関する総合調查報告 (II). 文部省科 学研究費報告書, 東京.]

Davenport, C. B., M. Steggerda and W. DRAGER, 1934: Critical examination of physical anthropometry on the living. Proc. Am. Acad. Arts and Sci., 63: 265-284.

Gavan, J.A., 1950: The consistency of anthropometric measurements. Am. J. Phys. Anthrop., 
8: 417-426.

HiRata, K., 1950: On the difficulty of anthropometry. Acta Anat. Nippon., $25: 161-173$. (In Japanese)

[平田欽逸, 1950：身体計測の困難性について。解 剖学雑誌, $25: 161-173$.

Howells, W. W., 1973: Cranial variation in man: a study by multivariate analysis of patterns of difference among recent human populations. Papers of the Peabody Museum of Archaeology and Ethnology, Harvard University, 67: 1-259.

IKEDA, T. and H. TERAdA, 1977: Reliability of anthropometric data: comparison of two examiner groups. Jap. J. Ergonomics, $13: 247-253$. (In Japanese with English summary)

JAmison, P. and S.L. ZEGURA, 1974: A univariate and multivariate examination of measurement error in anthropometry. Am. J. Phys. Anthrop., 40: 197-204.

Kemper, H.C. G. and J. J. L. Pieters, 1974 : Comparative study of anthropometric measurements of the same subjects in two different institutes. Am. J. Phys. Anthrop., 40 : 341-344.

Kouchi, M. and K. Hanihara, 1981: An analysis of errors in somatometric research. J. Anthrop.
Soc. Nippon, $89: 493-504$.

MARTin, R. und K. SAller, 1957: Lehrbuch der Anthropologie, dritte Aufl., Bd. I. Gustav Fischer Verlag, Stuttgart.

NAKAO, K., T. IKEDA and Y. FuKushima, 1972 : Errors in the measurement of human body. Jap. J. Ergonomics, 8: 141-146. (In Japanese with English summary)

PAGE, J. W., 1976: A note on interobserver error in multivaiate analysis of populations. Am. J. Phys. Anthrop., 44 : 521-525.

SAKURA, H. and Y. MizOGUCHI, 1983: Measurement errors in craniometry. J. Anthrop. Soc. Nippon, 91:69-78. (In Japanese with English summary)

SoKAL, R.R. and F. J. RohlF, 1981: Biometry, 2nd ed. Freeman, San Francisco.

Spielman, R.S. et al., 1972: The genetic structure of a population, the Yanomama Indians. Am. J. Phys. Anthrop., 37 : 345-356.

Suzuki, S., 1935: A study on measurement errors. I. errors in height measurements. Taiiku Kenkyu, $3:$ 115-136. (In Japanese)

[鈴木繁, 1935：人体測定の誤差に関する研究. 第 一報. 高さの測定に打的る誤差について. 体育研究, 3: 115-136. ] 
抄

頭骨計測值の誤差

河内むき子・小泉清隆

\section{東京大学理学部人類学教室}

本研究の目的は, 実際のデータ分析において 計測ミスと計測誤差の影響をできるだけ小さく して合理的な分析結果を得るためにはどのよう な前処理が必要か，またどのような計測項目を 使用すべきかを検討することである。

この目的のため, 深川雲光院出土の江戸時代 人男性頭骨 35 個について, 26 項目の計測值を 10 人が 3 回計測した延べ 30 人分のデータを使用し て，不注意によるミスの頻度と種類を調べると 同時に, 計測者内・計測者間の誤差の分析を行 なった。以下，本文の各章について要約する。

1）約 900 個の計測值のうち拉よそ $0.8 \%$ が不 注意によるミスで，このうち約 7 割は $5 \mathrm{~mm}$ あ るいは $10 \mathrm{~mm}$ 単位の読み違いか記入場所の誤 りであった。これらのうち, 実際の值との差が $20 \mathrm{~mm}$ をこえるものは, 平均値 \pm 3 S.D. 以 上離れた計測值を取り除くスクリーニングで取 り除くことができる。

2) Nested analysis of variance 法により分 析した結果，すべての項目に执いて計測者間分 散は計測者内分散よりも有意に大きい。このう ち, 両耳幅, 眼窩幅 I, 眼窩幅 II, 矢状頭頂弧 長, 矢状頭頂弦長, 矢状後頭弧長, 矢状後頭弦 長, 眼窩高の 8 項目で全誤差分散が全分散の 10 \%をこえた (Table 1)。この結果は, 計測者が あまり確信を持たずに括弧付きで計測した值を 取り除いて子変わらない(Table 2)。

3）同時代・同地域の他集団（浄心寺, 東上 野, 雲光院 2) の計測值, および延べ30人分の データの中央値（雲光院 1 ）を加えた 34 集団間 の Penrose の Shape distance をクラスター
分析をした結果，上記 8 項目を除いた18項目の セットは計測誤差の面からみて信頼がおけるこ とが確認された(Figures 1-5)。

4) 雲光院頭骨 65 個について因子分析をした 結果, 上記 8 項目のうち, 眼窩高はどの因子と も相関が低い。また, 両耳幅, 眼窩幅 I と眼窩 幅II, 矢状後頭弧長と矢状後頭弦長は 3 つの因 子への寄与が高いが，これらの因子には他にも 相関が高い項目がある。したがって，これらを 使用しなくても情報の損失はあまりない。しか し, 矢状頭頂弧長, 矢状頭頂弦長を取り除いた 場合には頭頂部に関する情報が失われる(Table 3)。

5）26項目を用いた場合と，18項目を用いた 場合の Shape distance の相関は高く, 8 項目 を取り除いても集団間の関係はあまり変わらな い。18項目に基づいた距離で, 計測ミスがない 場合と計測ミスはあるが平均值 \pm 3 S. D. 以上 離れた計測值を取り除くスクリーニングをした ものとの相関は 1.0 である (Table 4)。

実際に計測する際には，いくら注意深く計測 しても不注意によるミスは避けられないもので ある。本研究のように極めて類似性の高い集団 を分析する際には，このような計測ミスが分析 結果に与える影響は大きい。この影響を小さく するためにこのスクリーニングは極めて有効で ある。同様に, 形態的差異の小さい集団を分析 する際には計測誤差の影響も無視できない。計 測者間誤差の大きい項目を使用して分析すると, 集団間の差ではなく, 計測者間の差を比較して しまうことになりかねない。日本人の地域性を 
分析するような類縁性の高い集団を比較する際 択して分析する方が望ましい。 には，誤差の少なく信頼性の高い項目だけを選

河内まき子東京大学理学部人類学教室

T113 東京都文京区本郷 7-3-1

Makiko KoUchI Department of Anthropology, Faculty of Science, the

University of Tokyo, 7-3-1 Hongo, Bunkyo-ku, Tokyo 113, Japan 